\title{
Backcrosses in a segregating population of Passiflora mediated by morphoagronomic and resistance traits
}

Valquíria Oliveira dos Santos, Alexandre Pio Viana, Sandra da Costa Preisigke, Eileen Azevedo Santos* Universidade Estadual do Norte Fluminense Darcy Ribeiro - Centro de Ciências e Tecnologias Agropecuárias - Laboratório de Melhoramento Genético Vegetal - Campos dos Goytacazes (RJ), Brazil.

\begin{abstract}
The present study aims to characterize the genetic diversity of Passiflora setacea, P. edulis, their hybrids, and firstbackcross progenies, and to indicate promising recombinants for generation advancement in a breeding program for transferring resistance to cowpea aphid-borne mosaic virus (CABMV). Ninetyone genotypes were evaluated for 37 morphoagronomic descriptors. The traits were analyzed to obtain a distance matrix, based on the Gower algorithm, using the Ward-Modified Location Model (MLM) procedure for the composition of genetic groups. The adopted strategy led to the formation of five homogeneous groups, where
\end{abstract}

groups I, III, and V comprised the parents P. setacea, P. edulis and interspecific hybrids, respectively, while groups II and IV consisted of 69 genotypes of $\mathrm{BC}_{1}$. Broad variability was observed among the tested genotypes, and the highest was shown by group IV. Genotypes 17, 293, 355, and 501, from group IV, were the most promising for the second backcross cycle as they showed good resistance to the disease and desirable morphoagronomic traits.

Key words: breeding, Sour passionfruit, ward-mIm, cabmv, Morphoagronomic characterization. 


\section{INTRODUCTION}

Most Passiflora species originated in Tropical and subtropical America can be found from Southern North America to Northeastern Argentina. Brazil is one of the main genetic diversity centers of this family (Bernacci et al. 2013). In the Brazilian scenario, passion fruit stands out as a crop with great potential for cultivation, marked expansion, and great popularization in domestic market (Ataíde et al. 2012).

Passiflora edulis Sims, known simply as "passion fruit" (or "sour passion fruit", in Brazil), is the main commercial species thanks to its quality, vigor, and juice yield (Silva et al. 2014). The average yield of this species attained in the Brazilian orchards in the last ten years was $15.6 \mathrm{t} \cdot \mathrm{ha}^{-1}$, and its production potential reaches over $40 \mathrm{t}^{\mathrm{h}} \mathrm{ha}^{-1}$ (IBGE 2017). Among the factors responsible for the low yield of passion fruit in Brazil, diseases are those that most limit the expansion of cultivated areas; in some cases, they even lead to complete crop loss (Santos et al. 2015 b).

The fruit hardening (woodiness) caused by the Cowpea aphid-borne mosaic virus (CABMV) is an important disease that affects the passion fruit crop in Brazil and limits fruit production, causing significant production losses. After being infected, the plant shows a common mosaic, wrinkling, distortion, and reduction in its foliar area, and smaller, deformed fruits with a hardened pericarp, which leads to decreased yield and low fruit quality (Cerqueira-Silva et al. 2014).

Because there are no P. edulis cultivars resistant to woodiness induced by CABMV, the introgression of resistance genes through interspecific crosses has been a successful strategy. The species $P$. setacea is resistant to CABMV and has a high genetic compatibility with passion fruit (Santos et al. 2014; Sacoman et al. 2017). In 2009, the State University of Northern Rio de Janeiro started a breeding program aimed at the development of passion fruit varieties resistant to CABMV through interspecific hybridizations. Segregating populations obtained from the cross between $P$. edulis and P. setacea were evaluated for resistance to CABMV and for morphoagronomic traits (Santos et al. 2014; Santos et al. 2015 a, b). The hybrids that included good yield and resistance to CABMV were selected by the REML/ BLUP strategy to be crossed with P. edulis, constituting the first backcross generation $\left(\mathrm{BC}_{1}\right)$ (Freitas et al. 2016). An initial study of heritability was undertaken with $\mathrm{BC}_{1}$ and the hypothesis of monogenetic inheritance was discarded (Freitas et al. 2015). Despite the fact that it is a complex inheritance, tolerant genotypes can be obtained provided that populations with a satisfactory effective number are used (Viana and Resende 2014).
Studies involving segregating populations, especially those originating from interspecific crosses, require characterization and evaluation of the genetic material so that the breeder can know and properly handle the available variability within a breeding program. Multivariate methods contribute to this purpose, as they are proposed to evaluate a group of individuals for several traits simultaneously, allowing the identification of promising crosses (Santos et al. 2014).

Of the multivariate methods, the Ward-Modified Location Model (MLM) procedure, proposed by Franco et al. (1998), has the advantage of using all the available information on the quantitative and qualitative variables of the germplasm in question. Further, it allows the definition of the optimal number of groups and the calculation of a measurement of the groups with high precision, since it provides a reliable identification of the best probability of each genotype being allocated into specific groups (Paiva et al. 2014). This method has been widely employed in recent years, especially in genetic diversity studies of Passiflora (Paiva et al. 2014), to support breeding programs via recurrent selection in passion fruit (Silva et al. 2014), in a segregating Passiflora population aiming at resistance to CABMV (Santos et al. 2014), and in ornamental Passiflora species (Melo et al. 2015).

For the continuity of the passion fruit selective-breeding program aimed at resistance to $\mathrm{CABMV}$, this study proposes i) to characterize species, hybrids, and populations obtained from the first Passiflora backcross based on morphoagronomic descriptors; ii) to estimate the genetic diversity among the studied genotypes based on a combined analysis of quantitative and multi-trait variables through the Ward-MLM procedure; and iii) to indicate promising recombinants for generation advancement in the passion fruit selective-breeding program of State University of Northern Rio de Janeiro Darcy Ribeiro.

\section{MATERIAL AND METHODS Evaluated populations}

The genotypes used in this study originated from the passion fruit selective-breeding program of the University of Northern Rio de Janeiro Darcy Ribeiro (UENF). Ninety-one genotypes were evaluated, consisting of: one genotype of P. setacea (resistant), four genotypes of P. edulis (recurrent and susceptible parent), their hybrids (resistance genes donor parent-14 genotypes) and five full-sib family (72 $\mathrm{BC}_{1}$ genotypes) (Table 1, Fig. 1). 
Table1. Passiflora edulis and P. setacea genotypes, interspecific hybrids, and $\mathrm{BC}_{1}$ individuals used in thestudy of genetic diversity and their respective origins.

\begin{tabular}{|c|c|c|c|}
\hline Genotypes & Origin $q \mathbf{x} \widehat{\jmath}$ & Genotypes & Origin $q \mathbf{x}$ \\
\hline P. setacea. 1 & Banco de germoplasma UENF & $\mathrm{BC}_{1} 155$ & H5-14 x P. edulis \\
\hline P. edulis. 7 & UENF ‘Rio Dourado’^ & $\mathrm{BC}_{1} 160$ & H5-14 x P. edulis \\
\hline P. edulis. 9 & UENF ‘Rio Dourado’^ & $\mathrm{BC}_{1} 161$ & H5-14 x P. edulis \\
\hline P. edulis. 10 & UENF ‘Rio Dourado’* & $\mathrm{BC}_{1} 174$ & H5-14 x P. edulis \\
\hline P. edulis. 11 & UENF ‘Rio Dourado’* & $\mathrm{BC}_{1} 180$ & H5-14 x P. edulis \\
\hline $\mathrm{H} 1-15.5$ & P. edulis 139 x P. setacea 367 & $\mathrm{BC}_{1} 193$ & $\mathrm{H} 1-15 \times$ P. edulis \\
\hline $\mathrm{H} 1-15.8$ & P. edulis 139 x P. setacea 367 & $\mathrm{BC}_{1} 198$ & $\mathrm{H} 1-15 \times$ P. edulis \\
\hline $\mathrm{H} 1-15.9$ & P. edulis 139 x P. setacea 367 & $\mathrm{BC}_{1} 199$ & $\mathrm{H} 1-15 \times$ P. edulis \\
\hline H5-13. 1 & P. setacea $367 \times$ P. edulis 139 & $\mathrm{BC}_{1} 200$ & $\mathrm{H} 1-15 \times$ P. edulis \\
\hline $\mathrm{H} 5-13.5$ & P. setacea $367 \times$ P. edulis 139 & $\mathrm{BC}_{1} 225$ & $\mathrm{H} 1-15 \times$ P. edulis \\
\hline $\mathrm{H} 5-13.7$ & P. setacea 367 x P. edulis 139 & $\mathrm{BC}_{1} 227$ & $\mathrm{H} 1-15 \times$ P. edulis \\
\hline H5-13. 9 & P. setacea $367 \times$ P. edulis 139 & $\mathrm{BC}_{1} 246$ & H5-16 x P. edulis \\
\hline H5-13.11 & P. setacea 367 x P. edulis 139 & $\mathrm{BC}_{1} 251$ & H5-16 x P. edulis \\
\hline H5-13.12 & P. setacea $367 \times$ P. edulis 139 & $\mathrm{BC}_{1} 253$ & H5-16 $\times$ P. edulis \\
\hline H5-14. 8 & P. setacea 367 x P. edulis 139 & $\mathrm{BC}_{1} 254$ & H5-16 x P. edulis \\
\hline H5-14.12 & P. setacea $367 \times$ P. edulis 139 & $\mathrm{BC}_{1} 259$ & H5-16 x P. edulis \\
\hline H5-16. 1 & P. setacea 367 x P. edulis 139 & $\mathrm{BC}_{1} 261$ & H5-16 x P. edulis \\
\hline H5-16. 6 & P. setacea $367 \times$ P. edulis 139 & $\mathrm{BC}_{1} 266$ & H5-16 x P. edulis \\
\hline H5-16. 9 & P. setacea 367 x P. edulis 139 & $\mathrm{BC}_{1} 268$ & H5-16 x P. edulis \\
\hline $\mathrm{BC}_{1} 13$ & H5-14 x P. edulis & $\mathrm{BC}_{1} 290$ & H5-1 x P. edulis \\
\hline $\mathrm{BC}_{1} 17$ & H5-14 x P. edulis & $\mathrm{BC}_{1} 293$ & $\mathrm{H} 2-10 \times$ P. edulis \\
\hline $\mathrm{BC}_{1} 22$ & H5-14 x P. edulis & $\mathrm{BC}_{1} 317$ & H5-14 x P. edulis \\
\hline $\mathrm{BC}_{1} 29$ & H5-14 x P. edulis & $\mathrm{BC}_{1} 320$ & H5-14 x P. edulis \\
\hline $\mathrm{BC}_{1} 33$ & H5-14 x P. edulis & $\mathrm{BC}_{1} 324$ & H5-14 x P. edulis \\
\hline $\mathrm{BC}_{1} 37$ & H5-14 x P. edulis & $\mathrm{BC}_{1} 335$ & H5-14 x P. edulis \\
\hline $\mathrm{BC}_{1} 38$ & H5-14 x P. edulis & $\mathrm{BC}_{1} 342$ & H5-14 x P. edulis \\
\hline $\mathrm{BC}_{1} 46$ & $\mathrm{H} 1-15 \times$ P. edulis & $\mathrm{BC}_{1} 355$ & $\mathrm{H} 1-15 \times$ P. edulis \\
\hline $\mathrm{BC}_{1} 47$ & $\mathrm{H} 1-15 \times$ P. edulis & $\mathrm{BC}_{1} 363$ & $\mathrm{H} 1-15 \times P$. edulis \\
\hline $\mathrm{BC}_{1} 50$ & $\mathrm{H} 1-15 \times$ P. edulis & $\mathrm{BC}_{1} 386$ & H5-16 x P. edulis \\
\hline $\mathrm{BC}_{1} 65$ & $\mathrm{H} 1-15 \times$ P. edulis & $\mathrm{BC}_{1} 387$ & H5-16 x P. edulis \\
\hline $\mathrm{BC}_{1} 67$ & H1-15 x P. edulis & $\mathrm{BC}_{1} 391$ & H5-16 x P. edulis \\
\hline $\mathrm{BC}_{1} 75$ & $\mathrm{H} 1-15 \times$ P. edulis & $\mathrm{BC}_{1} 399$ & H5-16 x P. edulis \\
\hline $\mathrm{BC}_{1} 79$ & $\mathrm{H} 1-15 \times P$. edulis & $\mathrm{BC}_{1} 412$ & H5-16 x P. edulis \\
\hline $\mathrm{BC}_{1} 80$ & $\mathrm{H} 1-15 \times P$. edulis & $\mathrm{BC}_{1} 421$ & H5-16 x P. edulis \\
\hline $\mathrm{BC}_{1} 81$ & H5-16 x P. edulis & $\mathrm{BC}_{1} 448$ & $\mathrm{H} 2-10 \times$ P. edulis \\
\hline $\mathrm{BC}_{1} 85$ & H5-16 x P. edulis & $\mathrm{BC}_{1} 461$ & H5-14 x P. edulis \\
\hline $\mathrm{BC}_{1} 87$ & H5-16 x P. edulis & $\mathrm{BC}_{1} 464$ & H5-14 x P. edulis \\
\hline $\mathrm{BC}_{1} 91$ & H5-16 x P. edulis & $\mathrm{BC}_{1} 484$ & H5-14 x P. edulis \\
\hline $\mathrm{BC}_{1} 94$ & H5-16 x P. edulis & $\mathrm{BC}_{1} 501$ & $\mathrm{H} 1-15 \times$ P. edulis \\
\hline $\mathrm{BC}_{1} 99$ & H5-16 $\times$ P. edulis & $\mathrm{BC}_{1} 545$ & H5-16 $\times$ P. edulis \\
\hline $\mathrm{BC}_{1} 101$ & H5-16 x P. edulis & $\mathrm{BC}_{1} 553$ & H5-16 x P. edulis \\
\hline $\mathrm{BC}_{1} 109$ & H5-16 x P. edulis & $\mathrm{BC}_{1} 554$ & H5-16 x P. edulis \\
\hline $\mathrm{BC}_{1} 113$ & H5-16 x P. edulis & $\mathrm{BC}_{1} 555$ & H5-16 x P. edulis \\
\hline $\mathrm{BC}_{1} 135$ & H5-1 x P. edulis & $\mathrm{BC}_{1} 586$ & H5-1 x P. edulis \\
\hline $\mathrm{BC}_{1} 137$ & H5-1 x P. edulis & $\mathrm{BC}_{1} 595$ & H5-1 x P. edulis \\
\hline $\mathrm{BC}_{1} 147$ & $\mathrm{H} 2-10 \times$ P. edulis & & \\
\hline
\end{tabular}

*Cultivar obtained by Recurrent Selection Program of UENF. 


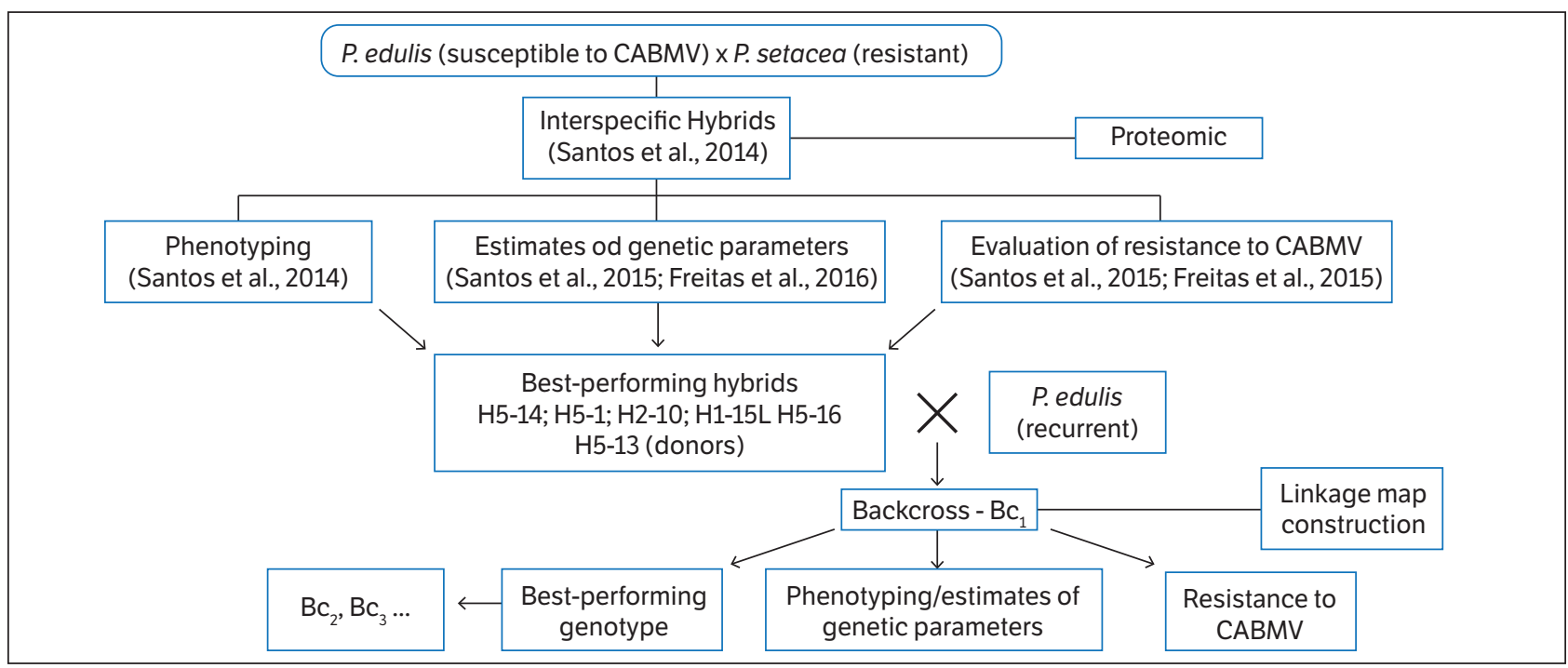

Figure 1: Flow-chart of the stages of the passion fruit selective-breeding program for resistance to the Cowpea aphid-borne mosaic virus (CABMV) of the State University of Northern Rio de Janeiro. Campos dos Goytacazes, 2017.

\section{Development of Backcross population}

The backcrosses were made in the experimental area of the Antônio Sarlo State Agricultural Technical School, located in Campos dos Goytacazes - RJ, Brazil (210 $45^{\prime} \mathrm{S}$, $41^{\circ} 20^{\prime} \mathrm{W}, 11 \mathrm{~m}$ altitude), where the hybrids obtained by Santos et al. (2015 a, b) were trained. Pollinations were carried out before flower opening, starting at 10:00 am. By that time, the P. edulis anthers were already open. P. edulis genotypes were used as male parents and the interspecific hybrid was used as the female parent. The flower buds of the parents were protected in the morning $(7: 00 \mathrm{am})$. The hybrids were emasculated and pollinated with pollen from the P. edulis genotypes and subsequently protected. These crosses originated five $\mathrm{BC}_{1}$ full-sib families.

\section{Plant propagation}

The interspecific hybrid was propagated asexually via herbaceous cuttings rooted into 72-cell trays containing organic substrate and maintained in a fog chamber until complete rooting. Subsequently, rooted cuttings were transplanted to black polyethylene plastic bags and kept in a greenhouse. Seminal propagation of these hybrids would not be desirable as they would generate segregating individuals for all traits including resistance to CABMV. The donor parent P. edulis is UENF's cultivar "Rio Dourado", originating from the recurrent selection program of passion fruit developed by UENF, commercially propagated by seeds. Seeds obtained from the full-sib family were washed in running water and kept for $15 \mathrm{~min}$ in a solution of $50 \%$ sodium hypochlorite and $50 \%$ water. After washing, seeds were sown in a 128-cell Styrofoam tray containing organic substrate and maintained in a fog chamber until the seedling stage. Subsequently, seedlings were transplanted to black polyethylene bags with 1-L capacity containing vegetable soil, substrate, and sand (1:1:1 ratio) and transferred to a greenhouse.

\section{Experimentation}

After 95 days, seedlings were transplanted to the experimental area of the Antônio Sarlo State Agricultural Technical School, Northern Rio de Janeiro State, Brazil $\left(21^{\circ} 45^{\prime}\right.$ lat, $41^{\circ} 20^{\prime} \mathrm{W}$ long, and $11 \mathrm{~m}$ alt), as a randomizedblock design with four replicates.

The plant-training system was vertical stalking with two $2.5-\mathrm{m}$ high posts spaced $4 \mathrm{~m}$ apart, with a wire No. 12 , at $1.80 \mathrm{~m}$ from the ground. The distance between planting rows and between furrows was $3.5 \mathrm{~m}$ and $2 \mathrm{~m}$, respectively. The cultivation treatments applied were those recommended for the passion fruit crop.

\section{Morphological characterization}

The first fructification took place in March 2016. The periods of harvest, evaluation of fruits, and evaluation of the vegetative and floral morphological traits occurred throughout the entire year of 2016 until the first quarter of 2017. 
Genotypes were characterized based on the morphoagronomic descriptors used for registration and protection of passion fruit cultivars developed by the National
Cultivar Protection Service of the Ministry of Agriculture, Livestock, and Supply (MAPA). Thirteen qualitative (Table 2) and 24 quantitative (Table 3) traits were evaluated.

Table2. Qualitative descriptors, and their respective observed classes, used to evaluate the 91Passiflora genotypes. UENF, Campos dos Goytacazes, 2017.

Descriptor

Color of the branch

Depth of the sinus

Leaf blade: pilosity

Position of leaf gland

Flower: hipanto shape

Flower: predominant coloring of the perianth

Flower: prevailing corona color

Flower: number of colored rings

Flower: long corona filaments

Flower: pollen

Fruit: shape

Fruit: prevailing skin color

Fruit: pulp color

\section{Classes observed according to the descriptors for Passifiora spp (MAPA)}

1: light green; 2: dark green; 3: green-purplish; 4: purple

3: shallow; 5: average; 7: deep.

1: absent; 2: present

1: adjacent to the leaf blade; 2 : close to the middle of the petiole; 3 : adjacent to the insertion of the leaf in the branch; 4 : distributed along the petiole.

1: flattened; 2 : campanulate; 3 : cylindrical

1: white; 2: pink; 3: red; 4: purplish-red; 5: purple; 6: purplish-blue; 7: blue

1: white; 2: pink; 3: red; 4: purplish red; 5: purple; 6: purplish-blue; 7: blue

1: one; 2 : more than one

1: smooth; 2: wavy

1: absent 2: present

1: oval; 2: oblong; 3: rounded; 4: oblate; 5 : ellipsoid; 6: fusiform; 7:piriformis; 8: oboval

1: green; 2: yellow; 3: orange; 4: pinkish; 5: red; 6: purple

1: whitish; 2: greenish-yellow; 3: yellow; 4: orange-yellow; 5: orange; 6: orange-dark; 7: red

Table 3. Quantitative descriptors used to evaluate the 91Passiflora genotypes and their respective observed classes. UENF, Campos dos Goytacazes, 2017.

\section{Descriptors ${ }^{1}$}

AUDPC

FRL (mm)

FRWI (mm)

FRWE (g)

$\operatorname{FPW}(\mathrm{g})$

$\mathrm{PT}(\mathrm{mm})$

TSS ( ${ }^{\circ}$ Brix)

$\mathrm{SS}(\mathrm{mm})$

NS

$\mathrm{SD}(\mathrm{mm})$

$\mathrm{LL}(\mathrm{mm})$

$\mathrm{LW}(\mathrm{mm})$

$\mathrm{PL}$ (mm)

$\mathrm{FL}(\mathrm{mm})$

FPL (mm)

PTL (mm)

PTW (mm)

$\mathrm{SPL}(\mathrm{mm})$

SPW (mm)

$\mathrm{BL}(\mathrm{mm})$

BW (mm)

$\mathrm{CD}(\mathrm{mm})$

$\mathrm{AL}(\mathrm{mm})$

CFL $(\mathrm{mm})$
Assessment method

Determined by scale of notes, according to the equation proposed by Campbell and Madden, (1990);

Determined in the longitudinal region of the fruits with the aid of a digital caliper - an average of 15 mature fruits;

Determined in the equatorial region of the fruits using a digital caliper - an average of 15 mature fruits;

Obtained with a digital semianalytical scale, with all mature fruits;

Weighing the pulp (seeds with arils), with the aid of the semianalitical balance;

Determined by the arithmetic mean of the measures of four points of the outer shell in the middle portion of the fruits, using a digital caliper;

Obtained by refractometry, using ATAGO N1 portable digital refractometer, with readings ranging from $0-32^{\circ}$ brix;

Ratio between length and width, with the sampling of ten seeds of 15 fruits

Manual counting (average of 15 fruits);

At the height of the first node of the main axis using a digital caliper;

Longitudinal extent of the highest edge - average of five leaves per plant, using digital caliper;

Transverse measurement of the largest dimension - average of five leaves per plant, using digital caliper;

From the insertion of the stem until the insertion of the leaf - average of five leaves per plant, using digital caliper;

From the extreme points of the flower, - average of five flowers per plant, using digital caliper;

From the insertion of the flower in the apex - average of five flowers per plant, using digital caliper;

Of the largest dimension - average of five flowers per plant, using digital caliper;

From the insertion in the flower to the apex - average of five flowers per plant, using digital caliper;

Of the largest dimension - average of five flowers per plant, using digital caliper;

From the insertion in the peduncle to the apex - average of five flowers per plant, using digital caliper;

Of the largest dimension - average of five flowers per plant, using digital caliper;

From the extreme points of the corona filaments - average of five flowers per plant, using digital caliper;

In the fullest extent that sustains the sexual organs - average of five flowers per plant, using digital caliper;

From the insertion in the flower receptacle up to the apex - average of five flowers per plant, using digital caliper;

${ }^{1} \mathrm{AUDPC}=$ area under the disease progress curve, $\mathrm{FRL}=$ fruit length, $\mathrm{FRWI}=$ fruit width, $\mathrm{FRWE}=$ fruit weight, FPW $=$ fruit pulp weight, $\mathrm{PT}=$ peel thickness, $\mathrm{TSS}=$ total soluble solids, $\mathrm{SS}=$ seed size, $\mathrm{NS}=$ number of seeds, $\mathrm{SD}=$ stem diameter, $\mathrm{LL}=$ leaf length, $\mathrm{LW}=$ leaf width, $\mathrm{PL}=$ petiole length, $\mathrm{FL}=$ flower length, $\mathrm{FPL}=$ flower peduncle length, $\mathrm{PTL}=$ petal length, $\mathrm{PTW}=$ petal width, $\mathrm{SPL}=$ sepal length, $\mathrm{SPW}=$ sepal width, $\mathrm{BL}=$ bractlength, $\mathrm{BW}=$ bract width, $\mathrm{CD}=$ corona diameter, $\mathrm{AL}=$ androgynophore length, and $\mathrm{CF} \mathrm{L}=\mathrm{corona}$ 'slong filamentlength. 
To evaluate the severity of the woodiness virus, plants were evaluated fortnightly after the first symptoms appeared. Symptoms were assessed visually using a scale of scores proposed by Novas and Rezende (1999) and modified by Oliveira et al. (2013) (Table 4). Based on these scores, the area under the disease progress curve (AUDPC) (Campbell and Madden 1990) was determined and an average was then estimated with the AUDPC values obtained for young leaves and for the whole plant.

Table 4. Scale of scores used for the evaluation of symptoms induced by CABMV in fruits and young leaves of passion fruit plants, with adaptations of Novaes and Rezende (1999); Oliveira et al. (2013). UENF, Campos dos Goytacazes, 2017.

\begin{tabular}{|c|c|c|c|}
\hline \multirow{2}{*}{ Note } & \multicolumn{3}{|c|}{ Symptoms of woodiness disease in passion fruit } \\
\hline & Young leaves & Fruits & Plants \\
\hline 1 & No symptoms & No symptoms & $\begin{array}{c}\text { No } \\
\text { symptoms }\end{array}$ \\
\hline 2 & $\begin{array}{l}\text { Mild mosaic, } \\
\text { node formation } \\
\text { of leaves }\end{array}$ & $\begin{array}{c}\text { Mildly } \\
\text { deformed }\end{array}$ & $\begin{array}{l}\text { Moderate quantity } \\
\text { of leaves with } \\
\text { mild mosaic and } \\
\text { wrinkling }\end{array}$ \\
\hline 3 & $\begin{array}{l}\text { Mild mosaic, } \\
\text { blisters and } \\
\text { deformation of } \\
\text { leaves }\end{array}$ & $\begin{array}{l}\text { Mildly } \\
\text { deformed, fruit } \\
\text { woodiness, } \\
\text { spots }\end{array}$ & $\begin{array}{l}\text { Moderate quantity of } \\
\text { leaves with mosaic } \\
\text { and leaf wrinkling }\end{array}$ \\
\hline 4 & $\begin{array}{l}\text { Severe mosaic, } \\
\text { blisters and } \\
\text { deformation of } \\
\text { leaves }\end{array}$ & $\begin{array}{l}\text { Totally } \\
\text { deformed, fruit } \\
\text { woodiness, } \\
\text { spots }\end{array}$ & $\begin{array}{l}\text { Large quantity of } \\
\text { leaves with mosaic, } \\
\text { severe wrinkling and } \\
\text { leaf deformation }\end{array}$ \\
\hline
\end{tabular}

\section{Statistical analysis}

The quantitative and qualitative variables (Tables 2 and 3) were analyzed simultaneously using the WardMLM procedure to form the groups of genotypes using the CLUSTER procedure and IML, of the SAS software system (SAS Institute 2009). The distance matrix (distfile) was obtained by the Gower algorithm (Gower 1971) for using the Ward grouping method. The optimal number of groups was defined according to the pseudo-F and pseudo- $\mathrm{t}^{2}$ criteria combined with the likelihood profile associated with the likelihood ratio test (SAS Institute 2009).

The Gower dissimilarity index was used because the set of variables under study formed a mixed group. The Gower index uses qualitative and quantitative data used for generating a single dissimilarity index ranging from 0 to 1 . The dissimilarity was given by:

$$
S i j=\frac{\sum_{k=1}^{p} W_{i j k} \cdot S_{i j k}}{\sum_{K=1}^{p} W_{i j k}}
$$

where $i$ and $j$ refer to the individuals to be compared with regard to the trait $k ; p=$ total number of traits, and $S_{i j}=$ contribution of the variable $k$ to the total distance. If a variable is qualitative, $S_{i j k}$ takes the value 1 when the concordance is positive or negative for the trait $k$ between individuals $i$ and $j$; and, on the other hand, when the variable is quantitative:

$$
S_{i j}=\frac{Y_{i k}-Y_{j k}}{R_{k}}
$$

where $R_{k}=$ the range of variation of the variable $k$, with values between 0 and 1 . The value of $W_{i j k}$ was used to define the contributions of $S_{i j k}$ individuals. Thus, when the value of the variable $k$ is absent in one or both individuals, $W_{i j k}=0$; otherwise, it is equal to 1 .

The dendrogram, obtained by the Ward method, was constructed using the R software, Dendextend package (R Development Core Team 2011) from the distfile file obtained by SAS.

\section{RESULTS AND DISCUSSION}

The Ward-MLM classification strategy, using quantitative and qualitative descriptors simultaneously for morphoagronomic traits, was efficient in distinguishing the 91 genotypes assessed. Based on the criteria of the pseudo-F and pseudo- $\mathrm{t}^{2}$ tests, the ideal number of homogeneous groups, clustered according to their similarities, was defined as five. This was due to the greater increase (of 72.39) in likelihood function that occurred in the fifth group (Fig. 2).

Based on the morphoagronomic descriptors, parents and hybrids were allocated to distinct groups, indicating broad genetic diversity in the evaluated genotypes. Group I was composed of one P. setacea genotype; group II, twelve $\mathrm{BC}_{1}$ genotypes; group III, four $P$. edulis genotypes and two $\mathrm{BC}_{1}$ individuals; group IV, $57 \mathrm{BC}_{1}$ genotypes; and group V, 15 genotypes, consisting of 14 interspecific hybrids and one $\mathrm{BC}_{1}$ individual (Fig. 3). 


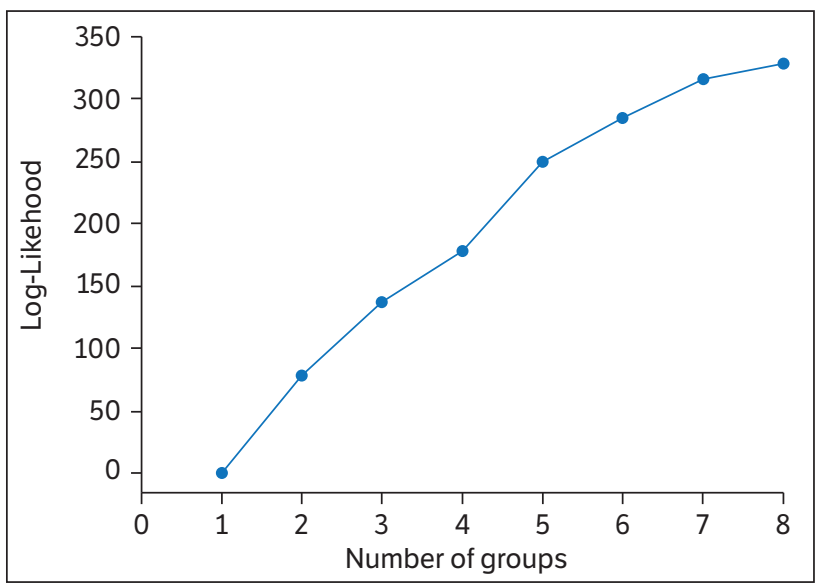

Figure 2. Graph of the log-likelihood function for the number of groups formed by the Ward-MLM strategy in $P$. edulis, $P$. setacea, interspecific hybrids, and $\mathrm{BC}_{1}$ genotypes. UENF, Campos dos Goytacazes, 2017.

As for the qualitative traits, group I was characterized by having pilose leaves with medium sinus depth and glands scattered along the petiole. The hypanthium was flat, with white perianth and corona, the latter of which was flat. Fruits had an oblong shape with green peel and whitish pulp (Table 5). Santos et al. (2014) evaluated a population obtained from the cross between P. edulis and P. setacea and observed that the $P$. setacea genotypes formed a single group, similarly to that obtained in this study, indicating that this species has peculiar traits both with respect to morphoagronomic attributes and resistance to CABMV.

In group $\mathrm{II}$, the $\mathrm{BC}_{1}$ genotypes were intermediate between $P$. edulis and P. setacea (Fig. 3). The members of that group showed non-pilose leaves, deep sinus, and majority of glands close to the middle of the petiole. However, there were genotypes with glands scattered along the petiole and adjacent to the blade. Half of the genotypes did not show pollen visible to the naked eye on the anthers, indicating a possible male sterility, which is common in interspecific crosses. Soares-Scott et al. (2003) evaluated interspecific Passiflora hybrids and found absence of pollen, development problems, low pollen viability, or difficulty flowering. The hypanthium of $75 \%$ of the genotypes was campanulated with the corona color white $(33 \%)$, pinkish (17\%), purple (33\%), or blue-purplish (17\%), whereas the perianth color was white or pink (Table 5). With respect to the fruits, $75 \%$ of the genotypes had a green peel, whereas the pulp color varied between yellow (50\%), yellow-orangish (25\%), and orangish (25\%) (Table 5).

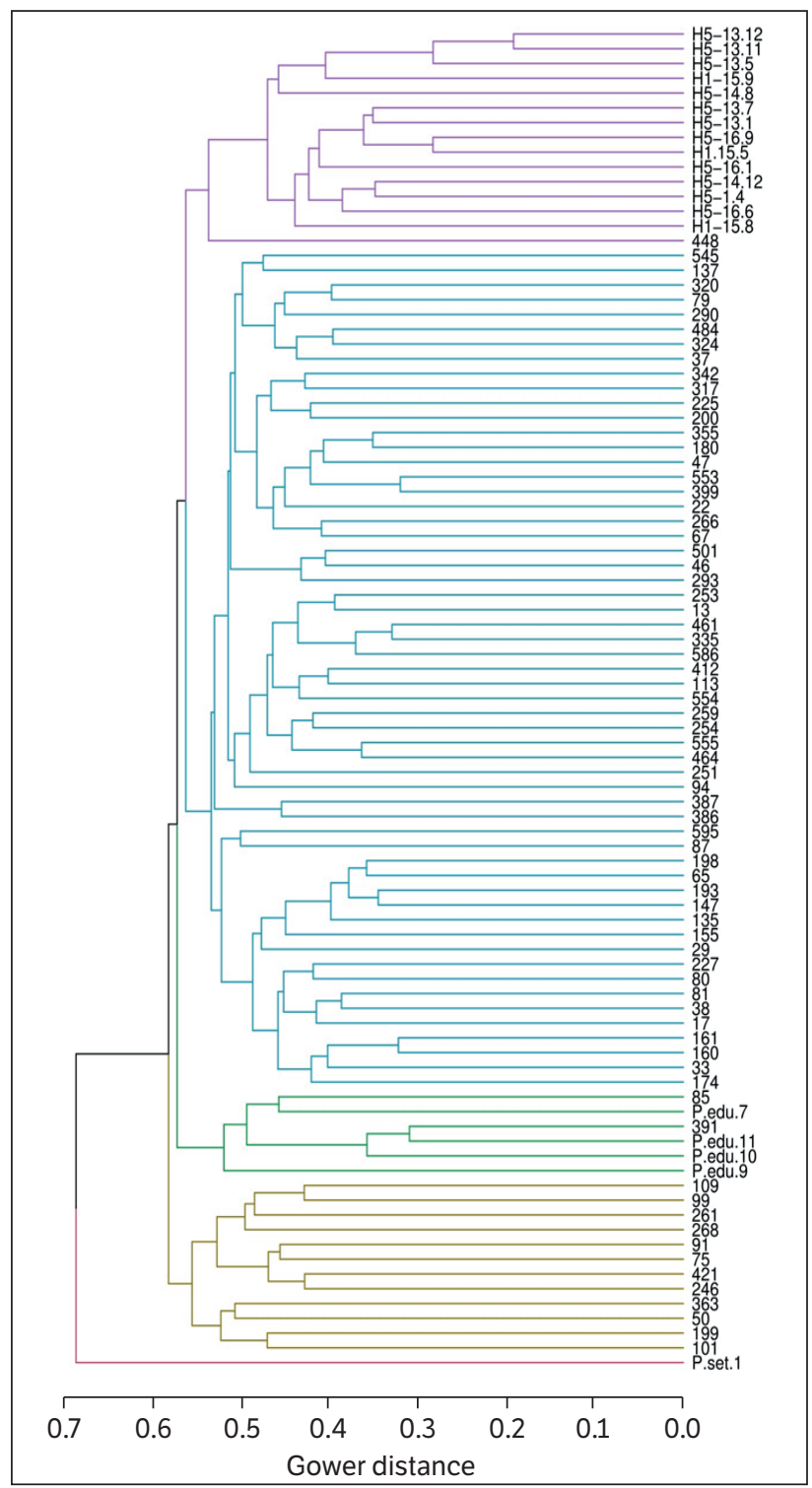

Figure 3. Dendrogram of genetic dissimilarity among 91 Passiflora genotypes, obtained by the Ward method, based on morphoagronomic and CABMV-resistance variables. UENF, Campos dos Goytacazes, 2017.

The individuals allocated in group III had glands adjacent to the leaf blade and a flat hypanthium. The corona color was mainly blue-purplish, whereas the perianth was mainly white. As for the fruit descriptors, the color of the peel and pulp was yellow, and the shape of the fruits was 50\% rounded and 50\% ellipsoid (Table 5). In morphoagronomic attributes, genotypes $\mathrm{BC}_{1} 85$ and 391 are more similar to the recurrent parent $P$. edulis (Table 5); however, they have high values for AUDPC, which makes their use as parents in future backcrosses with passion fruit not suitable (Table 6). 
Table 5. Descriptors and number of genotypes per group of qualitative traits in each of the five groups (GI, GII, GIII, GIV, and GV), formed by the UPGMA strategy, in P. edulis, $P$. setacea, interspecific hybrids, and $\mathrm{BC}_{1}$ genotypes. UENF, Campos dos Goytacazes, 2017.

\begin{tabular}{|c|c|c|c|c|c|c|}
\hline \multirow{2}{*}{\multicolumn{2}{|c|}{ Descriptors }} & \multicolumn{5}{|c|}{ Groups } \\
\hline & & \multirow{2}{*}{$\begin{array}{c}\text { G I } \\
\text { (1) } \\
1\end{array}$} & \multirow{2}{*}{$\begin{array}{c}\text { G II } \\
\mathbf{( 1 2 )}\end{array}$} & \multirow{2}{*}{$\begin{array}{c}\text { G III } \\
\text { (6) } \\
1\end{array}$} & \multirow{2}{*}{$\begin{array}{c}\text { G IV } \\
\text { (57) } \\
10\end{array}$} & \multirow{2}{*}{$\begin{array}{c}\text { G V } \\
\text { (15) } \\
3\end{array}$} \\
\hline \multirow{3}{*}{$\begin{array}{l}\text { Color of the } \\
\text { branch }\end{array}$} & Light green & & & & & \\
\hline & Dark green & - & 3 & - & 17 & 5 \\
\hline & Green-purplish & - & 4 & 5 & 30 & 7 \\
\hline \multirow{2}{*}{$\begin{array}{l}\text { Depth of the } \\
\text { sinus }\end{array}$} & Average & 1 & - & - & 3 & 3 \\
\hline & Deep & - & 12 & 6 & 54 & 12 \\
\hline \multirow{2}{*}{$\begin{array}{l}\text { Leaf blade: } \\
\text { pilosity }\end{array}$} & Absent & - & 12 & 6 & 57 & 15 \\
\hline & Present & 1 & - & - & - & - \\
\hline \multirow{3}{*}{$\begin{array}{l}\text { Position of } \\
\text { leaf gland }\end{array}$} & $\begin{array}{l}\text { Adjacent to the } \\
\text { leaf blade }\end{array}$ & - & 3 & 6 & 34 & - \\
\hline & $\begin{array}{l}\text { Middle of the } \\
\text { petiole }\end{array}$ & - & 8 & - & 22 & 15 \\
\hline & $\begin{array}{l}\text { Distributed along } \\
\text { the petiole }\end{array}$ & 1 & 1 & - & 1 & - \\
\hline \multirow{4}{*}{ Corona color } & White & 1 & 4 & - & 17 & 5 \\
\hline & Pinkish & - & 2 & 1 & 1 & - \\
\hline & Purple & - & 4 & - & 39 & 10 \\
\hline & Purplish-blue & - & 2 & 5 & - & - \\
\hline \multirow{3}{*}{$\begin{array}{l}\text { Hipanto } \\
\text { shape }\end{array}$} & Flattened & 1 & 2 & 6 & 16 & 15 \\
\hline & Campanulate & - & 9 & - & 26 & - \\
\hline & Cylindrical & - & 1 & - & 15 & - \\
\hline \multirow{4}{*}{$\begin{array}{l}\text { Coloring of } \\
\text { the perianth }\end{array}$} & White & 1 & 8 & 4 & 41 & 5 \\
\hline & Pinkish & - & 4 & 1 & 1 & 6 \\
\hline & Purple & - & - & - & 14 & 4 \\
\hline & Purplish-blue & - & - & 1 & 1 & - \\
\hline \multirow{2}{*}{$\begin{array}{l}\text { Long corona } \\
\text { filaments }\end{array}$} & Smooth & 1 & 6 & - & 28 & 14 \\
\hline & Wavy & - & 6 & 6 & 29 & 1 \\
\hline \multirow{2}{*}{$\begin{array}{l}\text { Number of } \\
\text { colored rings }\end{array}$} & One & 1 & - & - & - & 1 \\
\hline & More than one & - & 12 & 6 & 57 & 14 \\
\hline \multirow{2}{*}{ Pollen } & Present & 1 & 6 & 5 & 33 & 15 \\
\hline & Absent & & 6 & 1 & 24 & \\
\hline \multirow{6}{*}{ Shape fruit } & Oval & - & 1 & - & 20 & 6 \\
\hline & Oblong & 1 & - & - & 2 & - \\
\hline & Rounded & - & 4 & 3 & 22 & - \\
\hline & Oblate & - & - & - & 3 & - \\
\hline & Ellipsoid & - & 6 & 3 & 6 & 9 \\
\hline & Oboval & - & 1 & - & 4 & - \\
\hline \multirow{2}{*}{$\begin{array}{l}\text { Prevailing } \\
\text { skin color }\end{array}$} & Green & 1 & 9 & - & 31 & 12 \\
\hline & Yellow & - & 3 & 6 & 26 & 3 \\
\hline \multirow{4}{*}{ Pulp color } & Whitish & 1 & - & - & - & - \\
\hline & Yellow & - & 6 & 6 & 57 & 15 \\
\hline & Orange-yellow & - & 3 & - & - & - \\
\hline & Orange & - & 3 & - & - & - \\
\hline
\end{tabular}

Table 6. Mean values for quantitative variables for each of the five groups formed by the Ward-MLM method in P. edulis, P. setacea, interspecific hybrids, and $\mathrm{BC}_{1}$ genotypes. UENF, Campos dos Goytacazes, 2017.

\begin{tabular}{|c|c|c|c|c|c|}
\hline \multirow[b]{2}{*}{ Descriptors ${ }^{1}$} & \multicolumn{5}{|c|}{ Groups } \\
\hline & $\begin{array}{l}\text { G I } \\
\text { (1) }\end{array}$ & $\begin{array}{c}\text { G II } \\
\text { (12) }\end{array}$ & $\begin{array}{l}\text { G III } \\
\text { (6) }\end{array}$ & $\begin{array}{l}\text { G IV } \\
\text { (57) }\end{array}$ & $\begin{array}{c}\text { G V } \\
\text { (15) }\end{array}$ \\
\hline AUDPC & 386.2 & 667.1 & 946.0 & 626.7 & 556.7 \\
\hline $\mathrm{FRL}(\mathrm{mm})$ & 53.9 & 70.8 & 77.8 & 64.0 & 71.9 \\
\hline FRWI (mm) & 46.9 & 58.6 & 73.0 & 57.4 & 55.5 \\
\hline FRWE (g) & 50.9 & 70.3 & 134.0 & 60.9 & 51.6 \\
\hline FPW (g) & 24.7 & 27.6 & 59.7 & 21.8 & 17.1 \\
\hline PT (mm) & 5.2 & 7.5 & 9.5 & 7.9 & 6.8 \\
\hline TSS ( ${ }^{\circ}$ Brix) & 14.9 & 12.6 & 15.1 & 13.5 & 12.8 \\
\hline $\mathrm{SS}(\mathrm{mm})$ & 5.4 & 6.1 & 6.9 & 6.0 & 6.0 \\
\hline NS & 132.2 & 88.4 & 215.4 & 79,0 & 54.5 \\
\hline $\mathrm{SD}(\mathrm{mm})$ & 27.0 & 25.3 & 37.5 & 25.7 & 25.6 \\
\hline $\mathrm{LL}(\mathrm{mm})$ & 115.6 & 95.8 & 112.7 & 100.5 & 116.7 \\
\hline $\mathrm{LW}(\mathrm{mm})$ & 123.2 & 123.0 & 126.9 & 119.6 & 135.7 \\
\hline $\mathrm{PL}(\mathrm{mm})$ & 51.5 & 34.3 & 50.4 & 30.5 & 39.1 \\
\hline $\mathrm{FL}(\mathrm{mm})$ & 38.0 & 54.7 & 48.5 & 49.4 & 61.7 \\
\hline $\mathrm{FPL}(\mathrm{mm})$ & 58.7 & 58.4 & 47.9 & 47.9 & 72.0 \\
\hline PTL (mm) & 32.6 & 39.0 & 38.1 & 37.1 & 42.4 \\
\hline PTW (mm) & 6.4 & 10.9 & 12.2 & 11.0 & 9.9 \\
\hline $\mathrm{SPL}(\mathrm{mm})$ & 45.2 & 41.2 & 40.8 & 38.9 & 47.3 \\
\hline SPW (mm) & 4.9 & 7.7 & 8.8 & 8.0 & 7.5 \\
\hline $\mathrm{BL}(\mathrm{mm})$ & 17.5 & 22.7 & 26.1 & 22.9 & 29.5 \\
\hline $\mathrm{BW}(\mathrm{mm})$ & 16.6 & 16.0 & 18.8 & 16.3 & 24.1 \\
\hline $\mathrm{CD}(\mathrm{mm})$ & 36,5 & 75.7 & 69.8 & 73.9 & 76.4 \\
\hline $\mathrm{AL}(\mathrm{mm})$ & 36,8 & 21.9 & 23.3 & 23.0 & 31.8 \\
\hline CFL (mm) & 16,9 & 32.4 & 31.1 & 31.5 & 33.7 \\
\hline
\end{tabular}

${ }^{1} \mathrm{AUDPC}=$ area under the disease progress curve, $\mathrm{FRL}=$ fruit length, $\mathrm{FRWI}=$ fruit width, FRWE = fruit weight, FPW = fruit pulp weight, $\mathrm{PT}=$ peel thickness, TSS $=$ total soluble solids, $S S=$ seed size, $N S=$ number of seeds, $S D=$ stem diameter, $\mathrm{LL}=$ leaf length, $\mathrm{LW}=$ leaf width, $\mathrm{PL}=$ petiole length, $\mathrm{FL}=$ flower length, $F P L=$ flower peduncle length,$P T L=$ petal length,$P T W=$ petal width,$S P L=$ sepal length, $\mathrm{SPW}=$ sepal width, $\mathrm{BL}=$ bract length, $\mathrm{BW}=$ bract width, $\mathrm{CD}=$ corona diameter, $\mathrm{AL}=$ androgynophore length, and $\mathrm{CF}=$ = corona's long filament length.

Group IV had the largest number of genotypes, all $\mathrm{BC}_{1}$, and showed greater diversity when compared with the other groups. However, the pulp color variable did not present genetic variability, with all genotypes having a yellowish pulp. The pulp color may be an indicator of the quality of fruits intended for the industry, in which case there is a preference for yellow fruits (Maniwara et al. 2014). The predominant fruit shapes were oval (35\%) and rounded (39\%). According to Greco et al. (2014), oval fruits are preferred by the industries for having a higher pulp yield, 
which facilitates their marketing. Approximately, $54 \%$ of the genotypes had a green-peeled fruit when ripe, whereas the other $46 \%$ had a yellow peel. Yellow fruits are preferred by consumers in relation to green fruits, since the change in the passion fruit peel color during the maturation process is the most common to assess the degree of maturation of the fruit (Freire et al. 2014).

Group V consisted of the interspecific hybrids and one $\mathrm{BC}_{1}$ individual. All members of this group had glands near the middle of the petiole; approximately $66 \%$ of the genotypes showed a purple corona, while the other $34 \%$ had a white corona. The perianth color, in turn, was white (33\%), pink $(40 \%)$, or purple (27\%). All flowers had their hypanthium flattened and $93 \%$ of the corona filaments straight. The fruit shape ranged between oval and ellipsoid, and the pulp color of all genotypes was yellow. The predominant peel color was green (Table 5). Santos et al. (2014) evaluated these same hybrids and obtained results similar to those observed here. The authors selected the genotypes with the largest number of fruits and heaviest pulp to be the parents of the first backcross generation $\mathrm{BC}_{1}$ evaluated in the present study (Santos et al. 2014).

In the analysis of resistance to CABMV, of the five evaluated groups, group III showed the highest value for AUDPC (Campbell and Madden 1990) (946.00), while group I had the lowest result (386.25). This is due to the fact that group III contains the genotypes of the recurrent parent (P. edulis), known for being highly susceptible to CABMV. Passiflora setacea, in turn, allocated from group I, has a higher level of resistance to CABMV, which can be seen in other studies developed by our research group (Santos et al. 2015 b; Freitas et al. 2015; Santos et al. 2017). The AUDPC is used to evaluate the severity of the woodiness virus, and it has shown to be efficient in identifying susceptible genotypes with levels of resistance to the virus in other works involving passion fruit (Santos et al. 2015 b), P. setacea, and segregating populations (Santos et al. 2015 b; Freitas et al. 2015).

In terms of quantitative descriptors, group I showed the lowest means for the following floral traits: FL (38.04), PTL (32.69), PTW (6.46), SPW (4.92), BL (17.58), CD (36.53), AL (36.81), and CFL (16.99). As for the agronomic descriptors of their fruits, in this group, the genotypes produced the smallest fruits, with the lowest FRL, FRWI, FRWE, SS, and PT (53.91, 46.92, 50.93, 5.40, and 5.22, respectively) and the second highest TSS (14.94) (Table 6). Similar values were found by Santos et al. (2014) for most of the descriptors. In addition to resistance against CABMV, the genotype from group I (P. setacea) has desirable physico-chemical fruit traits for selective breeding, e.g. high soluble solids content and thinner peel (Ataíde et al. 2012).

Although group II displayed the lowest mean for TSS (12.62), the mean values of the agronomic descriptors of fruit and floral traits were those that most approached group III, where the recurrent parent $P$. edulis was allocated. Group II also showed the lowest androgynophore length (Table 6), which is a relevant descriptor in morphoagronomic evaluations of passion fruit for being directly related to pollination, which in turn is related to production. Shorter androgynophores reduce the height of the stigma in relation to the corona, facilitating pollination (Siqueira et al. 2009).

Group III contains the genotypes with the highest means for fruit traits [FRL (77.80), FRWI (73.09), FRWE (134.00), FPW (59.71), SS (6.92), NS (215.41), and TSS (15.16)] as well as the highest PT (9.59). The first backcross was found to contribute to increasing the mean of fruit traits in the segregating population. Breeding programs are aimed at selecting the genotypes with thinner peel, which may indicate a larger amount of pulp in the evaluated populations. Lúcio et al. (2013) reported that both the concentratedjuice industry and the fresh-fruit market consider the peel thickness a relevant factor for the classification of the fruit, as it is inversely related to the juice yield.

The $\mathrm{BC}_{1}$ genotypes allocated to group IV showed intermediate values to the parents for all quantitative descriptors assessed (Table 6). Group V, however, formed by the interspecific hybrids, contained the genotypes with higher means for LL (116.78), LW (135.75), FL (61.77), FPL (72.00), PTL (42.41), SPL (47.30), BL (29.55), BW (24.14), CD (76.47), and CFL (33.71) (Table 6). Similar results were found by Santos et al. (2014).

The knowledge of the morphoagronomic and resistance traits evaluated in this study is essential in plant breeding programs, especially for supporting future crosses in the selection-breeding program aimed at resistance to CABMV developed by UENF. By characterizing the genetic diversity of the obtained population, it is possible to identify genotypes agronomically superior and more resistant, such as individuals $17,293,355$ and 501, which may generate more-advantageous gains from selection. This study provides a more consistent foundation for the choice of the best genotypes that may be selected and backcrossed to generate superior genotypes throughout the breeding program. 


\section{CONCLUSIONS}

The Ward-MLM statistical procedure was efficient in discriminating the groups, demonstrating that the simultaneous analysis of qualitative and quantitative data is viable and can provide greater efficiency in the knowledge of divergence among genotypes.

In the present study, we proposed to identify the genotypes closest to the recurrent parent, featuring good agronomic traits and resistance to CABMV. When this is not possible, preference should be given to the most resistant genotypes. Therefore, genotypes 17, 293, 355 , and 501, allocated to group IV, may be selected as parents to obtain the second backcross generation $\left(\mathrm{BC}_{2}\right)$, as they have low values for AUDPC in addition to satisfactory production and quantity of pulp. Therefore, by evaluating an effective number of plants in $\mathrm{BC}_{2}$, it will be possible to select the genotypes most agronomically similar to passion fruit, with a satisfactory level of resistance.

\section{AUTHOR'S CONTRIBUTION}

Conceptualization, Santos V. O. and Viana A. P.; Methodology, Santos V. O., Viana A. P. and Santos E. A.; Investigation, Santos V.O. and Preisigke S. C.; Writing - Original Draft, Santos V. O., Santos E. A. and Viana, A.P.; Writing Review and Editing, Santos E. A.; Funding Acquisition, Viana A. P.; Resources, Viana A. P.; Supervision, Viana A. P.

\section{ORCID IDs}

\author{
V.O. Santos \\ (iD) https://orcid.org/0000-0001-8736-6387 \\ A.P. Viana \\ (iD) https://orcid.org/0000-0002-2475-4910 \\ S.C. Preisigke \\ https://orcid.org/0000-0002-9176-764X \\ E.A. Santos \\ https://orcid.org/0000-0001-8336-9839
}

\section{REFERENCES}

Abreu, S. P. M. (2011). Cultivo de maracujá-azedo. Centro de Apoio ao Desenvolvimento Tecnológico. Brasília: CDT/UnB. [Accessed on: March19,2019.] http://www.respostatecnica.org.br/dossie-tecnico/ downloadsDT/NTY4Mw==

Ataíde, E. M., Oliveira J. C. and Ruggiero, C. (2012). Florescimento e frutificação do maracujazeiro silvestre Passiflora setacea D. C. cultivado em Jaboticabal, SP. Revista Brasileira de Fruticultura, 34,377-381. https://doi.org/10.1590/S0100-29452012000200009

Bernacci, L. C., Cervi, A. C., Milward-de-Azevedo, M. A., Nunes, T. S., Imig, D. C. and Mezzonato, A. (2013). C. Passifloraceae. In Lista de Espécies da Flora do Brasil. Rio de Janeiro: Jardim Botânico. [Accessed on: March 19, 2019.] http://www.floradobrasil.jbrj.gov. br/jabot/floradobrasil/FB12506

Campbell, C. L. and Madden, L.V. (1990). Introduction to Plant Disease Epidemiology. New York: Willey. 1. [Accessed on: March 19, 2019.] https://www.cabdirect.org/cabdirect/abstract/ 19912305030

Cerqueira-Silva, C. B. M., Jesus, O. N., Santos, E. S. L., Corrêa, R. X. and Souza, A. P. (2014). Genetic breeding and diversity of the genus Passiflora: progress and perspectives in molecular and genetic studies. International Journal of Molecular Sciences, 15, 14122-14152. https://doi.org/10.3390\%2Fijms150814122

Freire, J. S., Calvacante, L., Rebequi, A. M., Dias, T. J., Brehm, M. A. and Santos, J. B. (2014). Quality of yellow passion fruitjuice with cultivation using different organic sources and saline water. Idesia (Arica), 32 , 79-87. https://doi.org/10.4067/S0718-34292014000100009

Freitas, J. C. O., Viana, A. P., Santos, E. A., Silva, F. H. L., Paiva, C. L., Rodrigues, R., Souza, M. M. and Eiras, M. (2015). Genetic basis of the resistance of a passion fruit segregant population to Cowpea aphid-borne mosaic virus (CABMV). Tropical Plant Pathology, 40, 291-297. https://doi.org/10.1590/0100-29452017607

Freitas, J. C. O., Viana, A. P., Santos, E. A. S., Paiva, C. L., Silva, F. H. L. and Souza. M. M. (2016). Sour passion fruit breeding: Strategy applied to individual selection in segregating population of Passiflora resistant to Cowpea aphid-born mosaic virus (CABMV). Scientia Horticulturae, 211, 241-247. https://doi.org/10.1016/j. scienta.2016.09.002

Gower, J. C. (1971). A general coefficient of similarity and some of its properties. Biometrics, Washington, 27, 857-874. https://doi. org/10.2307/2528823 
Greco, S. M. L., Peixoto, J. R. and Ferreira, L. M. (2014). Avaliação física, físico-química e estimativas de parâmetros genéticos de 32 genótipos de maracujazeiro-azedo cultivados no Distrito Federal. Bioscience Journal, 30, 360-370.

[IBGE] Instituto Brasileiro de Geografia e Estatística (2017). Banco de dados agregados: produção agrícola municipal. Sistema IBGE de recuperação automática-SIDRA. [Accessed 2017 October 18]. https://sidra.ibge.gov.br/

Lúcio, A. D., Storck, L., Krause, W., Gonçalves, R. Q. and Nied, A. H. (2013). Relações entre os caracteres de maracujazeiroazedo. Ciência Rural, 43, 225-232. https://doi.org/10.1590/ S0103-84782013000200006

Maniwara, P., Nakano, K., Boonyakia, T. D., Ohashi, S., Hiroi, M. and To Hyama, T. (2014). The use of visible and near infrared spectroscopy for evaluating passion fruit postharvest quality. Journal of Food Engineering, 143, 33-43. https://doi.org/10.1016/j. jfoodeng.2014.06.028

Melo, C. A. F., Souza, M. M., Sousa, A. G. R., Viana, A. P. and Santos, E. A. (2015). Multivariate analysis of backcross progeny of Passiflora L. (Passifloraceae) for pre-breeding genotype selection. Genetics and Molecular Research, 14, 15376-15389. https://doi. org/10.4238/2015.November.30.15

Novaes, Q. S. and Rezende, J. A. M. (1999). Possível aplicação do DAS-ELISA indireto na seleção de maracujazeiro tolerante ao 'Passionfruit Woodiness Virus'. Fitopatologia Brasileira, 24, 76-79.

Oliveira, E. J., Soares, T. L., Barbosa, C. J., Santos-Filho, H. P. and Jesus, O. N. (2013). Disease severity from passion fruit to identify sources of resistance in field conditions, SP. Revista Brasileira de Fruticultura, 35, 485-492. https://doi.org/10.1590/ S0100-29452013000200018

Paiva, C. L., Viana, A. P., Santos, E. A., Silva, R. N. O. and Oliveira, E. J. (2014). Diversidade genética de espécies do gênero Passiflora com o uso da estratégia WARD-MLM, SP. Revista Brasileira de Fruticultura, 36, 381-390. https://doi.org/10.1590/0100-2945-156/13

R Development Core Team. (2011). R: A language and environment for statistical computing. R Foundation for Statistical Computing, Vienna, Austria. [Accessed on: January 05, 2018] http://www.Rproject.org/
Sacoman, N. N., Santos, E. A., Carvalho, V. S. and Viana, A. P. (2018). Resistência ao Cowpea aphid-borne mosaic virus em genótipos de Passiflora setacea germinadas in vitro. Revista Brasileira de Fruticultura, 40, 1-10. https://doi.org/10.1590/0100-29452017607 Santos, E. A., Viana, A. P., Freitas, J. C. O., Souza, M. M., Paiva, C. L., Rodrigues, D. L. and Tavares, R. F. (2014). Phenotyping of Passiflora edulis, $P$. setacea, and their hybrids by a multivariate approach. Genetics and Molecular Research, 13, 9828-9845. https://doi. org/10.4238/2014.November.27.10

Santos, E. A., Viana, A. P., Oliveira, F. J. C., Rodrigues, D. L., Tavares, R. F., Paiva, C. L. and Souza, M. M. (2015 a). Genotype selection by REML/BLUP methodology in a segregating population from an interspecific Passiflora spp. crossing. Euphytica, 204, 1-115. https://doi.org/10.1007/s10681-015-1367-6

Santos, E. A., Viana, A. P., Freitas, J. C. O., Silva, F. H. L., Rodrigues, R. and Eiras, M. (2015 b). Resistance to Cowpea aphid-borne mosaic virus in species and hybrids of Passiflora: advances for the control of the passion fruit woodiness disease in Brazil. European Journal Plant Pathology, 143, 85-98. https://doi.org/10.1007/ s10658-015-0667-y

SAS Institute. (2009). SAS/STAT: User's guide. Version 9.2. Cary: SAS Institute.

Silva, F. H. L., Viana, A. P., Ferreira, R. T., Freitas, J. C. O., Santos, J. O. and Rodrigues, D. L. (2014). Measurement of genetic diversity in progenies of sour passion fruit by Ward-MLM methodology: astrategy for heterotic group formation. Revista Ciência e Agrotecnologia, 38, 123-1239. https://doi.org/10.1590/S1413-70542014000300003

Siqueira, K. M. M., Kill, L. H. P., Martins, C. F., Lemos, I. B., Monteiro, S. P. and Feitoza, E. A. (2009). Ecologia da polinização do maracujáamarelo, na região do Vale do Submédio São Francisco. Revista Brasileira de Fruticultura, 31, 1-12. https://doi.org/10.1590/ S0100-29452009000100003

Soares-Scott, M. D., Meletti, L. M. M. and Recco-Pimentel, S. M. (2003). Meiotic behaviour and pollen fertility in sexual and somatic hybrids of Passiflora species. Caryologia, Florence, 56, 129-138. https://doi.org/10.1080/00087114.2003.10589315

Viana, A. P. and Resende, M. D. V. (2014). Genética quantitativa no melhoramento de fruteiras. Rio de Janeiro: Interciência. 